\title{
The history of the INPA \\ capoeira based on ecological studies of Lecythidaceae
}

Ghillean T. Prance (")

\begin{abstract}
The Lecythidaceae of a $2500 \mathrm{~m}^{2}$ area of the secondary forest of INPA was studied. The 97 individuals of Lecythidaceae present indicated a high number of primary forest species. It is concluded that most of the area was not burnt when the original forest was cut, and the regeneration of primary forest species is much greater in areas which are not burnt over after felling. This is further supported by parallel studies of Bignoniaceae and Meliaceae of the same area.
\end{abstract}

\section{INTRODUCTION}

I was surprised by the number of Lecythidaceae present in the secondary forest, while I was making collections of the plants of the INPA campus in Manaus. The Lecythidaceae is a family which occurs predominantly in the primary forests around Manaus, but is poorly represented in the secondary forests, locally called capoeiras. The presence of so many Lecythidaceae indicates that this area of forest is not the normal type of secondary forest which grows after cutting and burning an area of primary forest. Accordingly a study was made of the ecology and distribution of the Lecythidaceae of $2500 \mathrm{~m}^{2}$ of the INPA forest.

\section{METHOD AND SITE DESCRIPTION}

An area of forest was chosen which was known to be rich in Lecythidaceae and in which a similar study of Bignoniaceae by Dr. Gentry of Missouri Botanical Garden had shown the presence of many primary forest species of that family. The area is situated below the bird lake on a slope. The path cleared for the main drainage pipeline served as a base line for the quadrat selected. An area of $50 \times 50 \mathrm{~m}$ was used and was divided into 5 strips of $50 \mathrm{x}$ $10 \mathrm{~m}$. "All individuals (including the smallest) of Lecythidaceae were found, marked, and mapped. Herbarium specimens were made of all individuals for identification and documentation purposes. Since almost all the individuals of Lecythidaceae are young trees or stump sprouts, all material was sterile. The herbarium Voucher material is field at INPA and NY under the numbers: Prance $23174-23209,23212-$ $23250,23257-23271$.

\section{RESUI.TS}

In the area studied $\left(2500 \mathrm{~m}^{2}\right)$ there were 97 individuals of 5 species of Lecythidaceae; see Table 1. One species Eschweilera odora (Poepp.) Miers was much commoner than the others, with $64.95 \%$ of the total.

\begin{tabular}{clcr}
$\begin{array}{l}\text { MAP } \\
\text { SYMBOL }\end{array}$ & \multicolumn{1}{c}{ SPECIES } & $\begin{array}{l}\text { NUMBER OF } \\
\text { INDIVIDUALS }\end{array}$ & $\%$ \\
A & $\begin{array}{l}\text { Eschweilera longipes } \\
\text { (Poit.) Miers }\end{array}$ & 12 & 12.37 \\
B & $\begin{array}{l}\text { Chytroma foetida R. } \\
\text { Knuth }\end{array}$ & 9 & 9.28 \\
C & $\begin{array}{l}\text { Eschweilera fracta R. } \\
\text { Knuth }\end{array}$ & 11 & 11.34 \\
D & $\begin{array}{l}\text { Holopyxidium jara- } \\
\text { num (Hub.) Ducke } \\
\text { Eschweilera odora } \\
\text { (Poepp.) Miers }\end{array}$ & 2 & 2.06 \\
E & 63 & 64.95
\end{tabular}

Table 1. Frequency of each species of Lecythidaceae in a $2500 \mathrm{~m}^{2}$ quadrat.

The bases of all individuals were examined, and it was found that ninety of the ninetyseven trees were growing from stump sprouts, rather than from seedlings. This indicates the capacity of these species for regeneration from sprouts, but it also indicates that the forest was not altogether burned over. Burning kills the primary forest trees and another type of secondary forest with many species of $\mathrm{Ce}$ cropia etc. occurs.
(*) - Instituto Nacional de Pesquisas da Amazônia.
Botanical Garden.

B. A: Krukoff Curator of Amazonlan Botany, The New York 


\begin{tabular}{|c|c|c|c|c|}
\hline & I & II & III & IV \\
\hline 1 & 4 & 3 & 6 & 1 \\
\hline 2 & 1 & 2 & 4 & 4 \\
\hline 3 & 3 & 3 & 2 & . 2 \\
\hline 4 & $8 \times 10$ & 3 & 2 & 1 \\
\hline 5 & 6 & 2 & 1.5 & 1.5 \\
\hline 6 & 4 & 2 & 3 & 2 \\
\hline 7 & 5 & 3 & 3 & 1.6 \\
\hline 8 & 5 & 2 & 2 & 3 \\
\hline 9 & 6 & 1.5 & $8 \times 10$ & 1.7 \\
\hline 10 & 2 & 1 & 1.5 & 2 \\
\hline 11 & 5 & 2 & 1.6 & $6 \times 8$ \\
\hline 12 & 2 & 1.7 & 1 & 2 \\
\hline 13 & 2 & 1.5 & 2 & 2 \\
\hline 14 & 1 & 1 & 1.5 & 2 \\
\hline 15 & 2 & 5 & 5 & 2 \\
\hline 16 & 2 & 3 & 2 & 1.5 \\
\hline 17 & - & 2 & 1.5 & 5 \\
\hline 18 & - & 1.5 & 1.7 & 5 \\
\hline 19 & - & 1.8 & 1.5 & - \\
\hline 20 & - & 1 & 1 & - \\
\hline 21 & - & 1 & 2 & - \\
\hline 22 & - & 1.2 & - & - \\
\hline 23 & - & 1.5 & - & - \\
\hline $2 !$ & - & 1 & - & - \\
\hline 25 & - & 1 & - & - \\
\hline 26 & - & 2 & - & - \\
\hline 27 & - & 2 & - & - \\
\hline 28 & - & 2 & - & - \\
\hline 29 & - & 5 & - & - \\
\hline so & - & 1 & - & - \\
\hline 31 & - & 2 & - & - \\
\hline 32 & - & 5 & - & - \\
\hline
\end{tabular}

Table 2. Tree heights in meters; $x$ diameter for larger trees.

Fig. 1 is a map of the distribution of the ninety-seven individuals in the area. It can be seen that the top ten meters or more of each section have few Lecythidaceae $(10 \mathrm{~m}$. below Line $(W-X)$. In that area there is also a much greater frequency of typical secondary forest trees, Cecropia sp. Croton sp. etc. This area is also full of pits, burnt soil and charcoal. Enquiries into the history of the forest and onsite observations show that the area was used for making charcoal. The area without primary forest trees corresponds with the area charcoal pits where the forest was completely cut and burnad. The area which is dense in young primary forest species, including the Lecythi- dacecie studied, corresponds with an area where the original forest was cut to obtain wood for charcoal, but the area was not burnt over. It can also be seen on the map (Fig. 1) that there is a greater density of Lecythidaceae tôwards the Line $X-Z$ than towards the Line
W-Y. I atiribute this to the slope of the quadrat. Line $X-Z$ runs along the highest part of the area, which slopes down gradually to Line $W-Y$ which is almost at the bottom of a small valey. Apparently the Lecythidaceae grow better on the upper part, a fact that is also supported by forest inventories in primary forest. Table 2 gives details of tree height showing that the individuals studied were young. Only one tree of Chytroma foetida was found in flower during the study.

A similar study of Bignoniaceae was made by Dr. Alwyn Gentry of Missouri Botanical Garden who also found that the area contained predominantly primary forest species. The Meliaceae of the area were studied by $\mathrm{Dr}$. T. D. Pennington of The Forest Herbarium, Oxford who also found Guarea duckei common in the quadrat. This is a species of primary forest and the majority of individuals were from stump sprouts. The Bignoniaceae were also from sprouts.

An interesting study of the regeneration of $3500 \mathrm{~m}^{2}$ of felled fores in the Ducke Forest Reserve $26 \mathrm{~km}$ from Manaus was recently made by $W$. Rodrigues (personal communication). The a! ea studied by Rodrigues was not burned and had much regeneration of primary forest trees. He found 74 individuals of Lecythidaceae, representing 14 species of 5 genera. Rodriguss study shows that there is much regeration of primary forest species in areas not subjected to burning.

\section{CONCLUSIONS}

The area studied is definitely secondary forest, but it is characterised by the presence of a large number of young trees and vines of primary forest species, mainly growing from stump sprouts. Secondary forest species, such as - Cecropia grow abundantly only in the part of the quadrat near to the former charcoal kilns, where burning took place.

This study demonstrates that, in areas where the forest is destroyed, the regeneration of the primary forest trees is much more rapid if burning does not take place. Thus, far less damage is done to the native gene pool when the forest is not burnt. This is true not only because of the propensity of many felled trees to regenerate from stump sprouts, but also because seed material is not destroyed. 


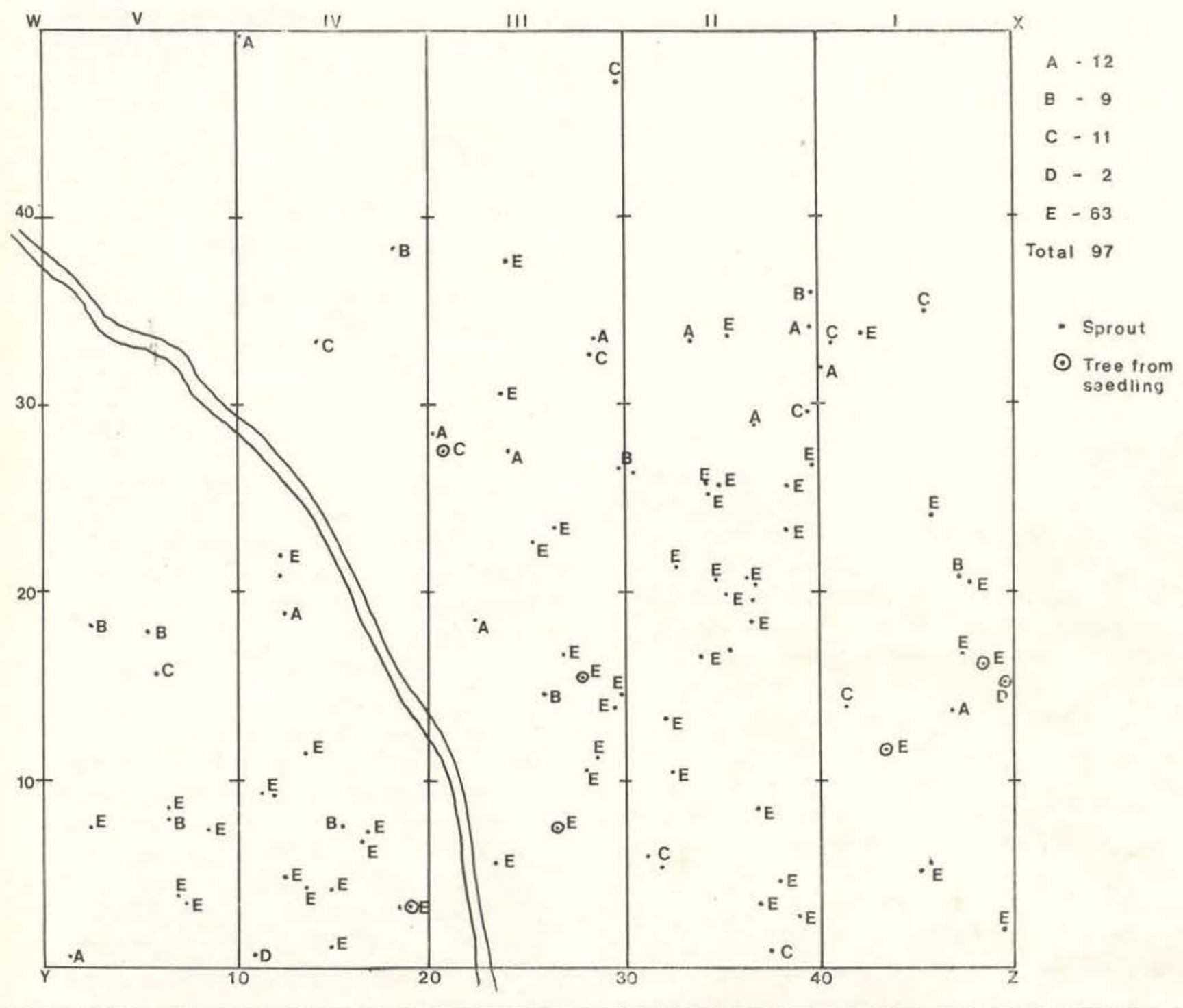

Fig. 1. Map of quadrat showing distribution of Lecythidaceae

\section{ACKNOWLEDGEMENTS}

I am grateful to Sr. José F. Ramos for carrying out much of the field work. The field work was supported by the National Science Foundation Grant BMS 75-03724, which is gratefully acknowledged. I would also like to thank Dr. William A. Rodrigues for allowing me to consult his unpublished data on regeneration, and Mrs. Anne Prance for preparing the map.

\section{SUMÁRIO}

Fez-se um estudo das Lecythidaceas de uma área de capoeira de $2500 \mathrm{~m}^{2}$, situada no Campus do INPA, Manaus. Foram encontrados 97 indivíduos ce cinco espécies da familia Lecythidaceae, sendo que 63 deles pertencem à espécie Eschweilera odora (Poepp.) Miers. Do total de individuos, 90 resultam de brotação de tocos das árvores origi nais. Observou-se que uma parte da área foi queimada, e lá ocorriam poucas Lecythidaceae, e muitas árvores típicas de capoeira. A parte que não sofreu a ação do fogo tem muitos representantes da familia (Lecythidaceae), mas também ocorrem cutras plantas características de mata primária, como por exemplo, espécimes das famílias Bignoniaceae e Meliaceae. Concluímos que grande parte da area nunca foi queimada, e nela a regeneração é muito mais rica em espécies de mata primária do que em uma área queimada. Isto porque muitas ảrvores têm capacidade de regeneração por brotação e muitas das sementes não chegam a ser destruídas. 